\title{
MODEL PEMBELAJARAN TALKING STICK DALAM MENINGKATKAN KETERAMPILAN MENGKOMUNIKASINKAN PEMBELAJARAN SEJARAH BAGI PESERTA DIDIK
}

\author{
Siti Anisa \\ Program Studi Pendidikan Sejarah FKIP Universitas Lambung Mangkurat \\ Banjarmasin \\ Email: nisa.sitianisa@gmail.com
}

\begin{abstract}
Abstrak: Suasana belajar yang menyenangkan, aktif dan bermakna bagi peserta didik perlu diciptakan dengan menerapkan model pembelajaran aktif bagi peserta didik. Proses pembelajaran yang berlangsung umunnya masih menggunakan metode ceramah, dimana guru menerangkan materi dan peserta didik mendengarkan serta mencatat saja. Salah satu model pembelajaran yang dapat diterapkan guru untuk meningkatkan keterampilan mengkomunikasikan pembelajaran sejarah bagi peserta didik yakni dengan menerapkan model pembelajaran talking stick atau tongkat berjalan.
\end{abstract}

Kata kunci : Model Pembelajaran, Talking Stick, Keterampilan Mengkomunikasikan, Pembelajaran Sejarah.

\section{PENDAHULUAN}

Pendidikan merupakan kebutuhan bagi setiap manusia sebab tanpa pendidikan manusia akan sulit berkembang sehingga pendidikan sangat penting bagi manusia. Tujuan pendidikan nasional menurut Undang-Undang Sistem Pendidikan Nasional Tahun 2003, Bab II Pasal 3 yaitu: “ Pendidikan nasional berfungsi mengembangkan dan membentuk watak serta peradaban bangsa yang bermanfaat dalam rangka mencerdaskan kehidupan bangsa, bertujuan untuk berkembangnya potensi peserta didik agar menjadi manusia yang beriman dan bertaqwa kepada Tuhanu Yang Maha Esa, berakhlak mulia, sehat, berilmu, cakap, kreatif, mandiri dan menjadi warga negara yang demokratis serta bertanggung jawab (Undang-Undang Republik Indonesia Nomor 20 Tahun 2003 Tentang Sistem Pendidikan Nasional)"

Pembelajaran bertujuan untuk mengarahkan peserta didik agar dapat menyesuaikan diri dengan lingkungan dan dapat bermanfaat dalam kehidupan bermasyarakat. Dari model pembelajaran talking stick ini dianggap dapat menciptakan peserta didik yang aktif dalam mengkomunikasi pembelajaran sejarah. Sehingga dengan menerapkan model pembelajaran talking stick ini diharapkan peserta didik dapat meningkatkan keterampilan mengkomunikasikan pembelajaran sejarah di dalam kelas. 


\section{MODEL PEMBELAJARAN TALKING STICK}

Konsep model pembalajaran menurut Trianto (2010: 51), menyebutkan bahwa model pembelajaran adalah suatu perencanaan atau pola yang digunakan sebagai pedoman dalam merencanakan pembelajaran di kelas atau pembelajaran tutorial. Model pembelajaran mengacu pada pendekatan pembelajaran yang akan digunakan, termasuk di dalamnya tujuan-tujuan pengajaran, tahap-tahap dalam kegiatan pembelajaran, lingkungan pembelajaran, dan pengelolaan kelas.

Pembelajaran adalah proses komunikasi antara guru dengan siswa dalam lingkungan belajar. Sehingga dalam proses pembelajaran harus di atur sedemikian rupa untuk tercapainya proses pembelajaran yang diinginkan. Proses pembelajaran dimulai dari perencanaan (penyusunan perangkat pembelajaran), kegiatan pembelajaran dan evaluasi pembelajaran. Ketiga proses ini berkesinambungan dan memiliki keterkatinan antar satu dengan yang lainnya. Perencanaan yang baikakan mempengaruhi kegiatan pembelajaran, sementara untuk mengetahui kualitas pembelajaran harus dilakukan evaluasi pembelajaran dan hasil evaluasi merupakan bahan pertimbangkan untuk emnyusun perencanan pembelajaran selanjutnya. (Heri Susanto, 2014 : 85).

Sejarah merupakan suatu proses perjuangan manusia dalam mencapai gambaran tentang segala aktivitasnya yang disusun sesuai secara ilmiah dengan memperhatikan urutan waktu, diberi tafsiran dan analisa kritik, sehingga mudah dimengerti dan dipahami. Sejarah dapat memberikan gambaran dan tindakan maupun perbuatan manusia dengan segala perubahannya.(Heri Susanto, 2014 : 7).

Pembelajaran sejarah merupakan interaksi antara guru dan peserta didik, antara sesama peserta didik, serta interaksi antara peserta didik dengan lingkungannya dalam merekonstruksi pengetahuan sejarah. Pembelajaran sejarah tidak hanya untuk mengetahui pengetahuan masa lampau tetapi juga tentang mengetahui masa kini, menumbuhkan adanya perkembangan masyarakat kebangsaan dan cinta tanah air serta kehidupan bangsa sebagai bangsa Indonesia.

Mempelajari sejarah terbentuknya negara kesatuan republik Indonesia berarti berusaha memahami bahwa negara ini terbentuk karena adanya sikap sosial yang baik dari para pendiri bangsa. Sikap sosial tersebut antara lain: saling menghormati, menghargai perbedaan, toleransi dan kesediaan untuk hidup berdampingan dalam nuansa multikulturalisme. Kesatuan yang terbentuk diatas perbedaan dalam proses kebangkitan nasional pada hakekatnya merupakan sikap sosial yang sangat patut diteladani (Heri Susanto, 2014 : 62).

Model pembelajaran talking stick merupakan salah satu metode pendukung pengembangan pembelajaran kooperatif. Pembelajaran kooperatif merupakan pembelajaran yang berbasis sosial, dengan membentuk kelompok kecil yang beranggotakan tiga orang atau lebih agar mempermudah proses pembelajaran. 
Menurut Agus Suprijono (2009:109) model pembelajaran talking stick adalah suatu model pembelajaran dengan bantuan tongkat, bagi siswa yang memegang tongkat terlebih dahulu wajib menjawab pertanyaan dari guru setelah peserta didik mempelajari materi pokoknya, selanjutnya kegiatan dari guru ini diulang terus menerus hingga semua peserta didik mendapatkan giliran untuk menjawab pertanyaan dari guru.

Sedangkan menurut Miftahul Huda (2013:224), talking stick merupakan metode pembelajaran kelompok dengan bantuan tongkat. Kelompok yang memegang tongkat wajib menjawab pertanyaan dari guru setelah membaca materi pokoknya. Kegiatan ini berlangsung berulang-ulang hingga setiap kelompok mendapatkan giliran menjawab pertanyaan.

Kegiatan pembelajaran dengan menerapkan model pembelajaran talking stick ini dapat membuat peserta didik lebih aktif dalam mengemukakan pendapat sehingga dapat melatih keterampilan mengkomunikasikan pembelajaran sejarah.

\section{KEBAIKAN MODEL PEMBELAJARAN TALKING STICK}

Model pembelajaran talking stick memiliki kebaikan atau kelebihan selama diterapkan oleh guru untu peserta didik kegiatan proses pembelajaran berlangsung. Menurut Imas dan Berlin (2016:83), kelebihan dari model pembelajaran talking stick ini adalah (1) menguji kesiapan peserta didik dalam menguasai materi, (2) melatih membaca dan memahami dengan cepat materi yang telah disimpaikan, (3) agar lebih giat belajar (belajar dahulu) karena peserta didik tidak pernah tau tongkat (stick) akan sampai pada gilirannya.

Kebaikan dari model pembelajaran talking stick ini dapat melatih siswa untuk dapat lebih giat belajar dan memahami materi pembelajaran agar ketika mendapatkan giliran untuk menjawab pertanyaan guru, peserta didik tersebut dapat dengan mudah menjawab pertanyaan tersebut juga dapat melatih peserta didik dalam meningkatkan keterampilan mengkomunikasin pembelajaran sejarah.

Adapun langkah-langkah dalam menerapkan model pembelajaran talking stick dikelas sebagai berikut:

1. Guru menyiapkan tongkat atau stick berukuran $20 \mathrm{~cm}$ yang akan menjadi alat dalam proses pembelajaran dikelas.

2. Setelah itu guru menyampaikan materi pembelajaran kepada peserta didik

3. Guru memberikan waktu sekitar 20 menit kepada peserta didik untuk memahami pembelajaran yang telah dijelaskan oleh guru serta mempersilahkan kepada peserta didik untuk membaca materi pokok pembelajaran di buku atau LKS yang digunakan pada saat proses pembelajaran dikelas.

4. Setelah waktu habis maka guru akan meminta peserta didik untuk menutup semua buku yang ada dimeja.

5. Guru memulai memainkan tongkat dengan diiringi musik daerah. 
6. Ketika musik masih menyala maka tongkat akan terus berpindah-pindah ke peserta didik.

7. Namun ketika musik berhenti maka peserta didik yang terakhir memegang tongkat tersebutlah yang akan menjawab pertanyaan dari guru.

8. Langkah-langkah tersebut akan terus terulang hingga semua peserta didik mendapatkan giliran untuk menjawab pertanyaan dari guru.

Sehingga dengan cara menerapkan model pembelajaran talking stick ini dapat membuat kelas menjadi lebih seru, peserta didik dapat lebih gembira dengan melakukan pembelajaran sambil bermain tongkat dan tentu peserta didik dapat lebih aktif dan mudah memahami pembelajaran sejarah.

\section{PENGGUNAAN MODEL PEMBELAJARAN TALKING STICK DALAM PEMBELAJARAN SEJARAH}

Dengan menerapkan model pembelajaran talking stick ini dikelas sangat membantu peserta didik untuk lebih aktif dalam belajar dikelas, karena dengan menerapkan model pembelajaran talking stick dapat dijadikan sebagai hiburan bagi peserta didik dimana guru mencoba mempermudah peserta didik untuk memahami materi dengan saling tanya jawab.

Model pembelajaran talking stick sangat cocok diterapkan dalam pembelajaran sejarah karena pembelajaran sejarah selama ini dianggap oleh peserta didik sebagai mata pelajaran yang membosankan, dimana hanya mengingat peristiwa dan waktu sejarah yang pernah terjadi di Indonesia maupun dunia. Sehingga dengan menerapkan model pembelajaran talking stick ini peserta didik diajak untuk memahami materi sejarah dengan cara yang santai dimana peserta didik diajak untuk bermain tongkat sambil dihidupkan musik, ketika musik nyala maka tongkat tersebut terus berjalan ke peserta didik namun jika musik berhenti peserta didik yang memegang tongkat tersebut wajib menjawab pertanyaan dari guru.

Model pembelajaran talking stick dengan cara menanyakan satu persatu pertanyaan ke peserta didik maka akan membuat peserta didik lebih aktif dan tentu juga akan melatih peserta didik dalam mengemukakan pendapat sehingga peserta didik dapat meningkatkan keterampilan mengkomunikasikan pembelajaran sejarah.

Dengan menerapkan model pembelajaran talking stick pada kegiatan pembelajaran dapat memberikan pengaruh baik dapat membantu peserta didik untuk lebih cepat memahami materi pembelajaran sejarah dan juga dengan cara mengemukakan pendapat atau jawaban dari pertanyaan tersebut dengan menggunakan bahasa sendiri tentu juga dapat meningkatkan keterampilan mengkomunikasikan pembelajaran sejarah peserta didik. 


\section{PENUTUP}

Menurut Agus Suprijono (2009:109) model pembelajaran talking stick adalah suatu model pembelajaran dengan bantuan tongkat, bagi siswa yang memegang tongkat terlebih dahulu wajib menjawab pertanyaan dari guru setelah peserta didik mempelajari materi pokoknya, selanjutnya kegiatan dari guru ini diulang terus menerus hingga semua peserta didik mendapatkan giliran untuk menjawab pertanyaan dari guru.

Dengan menerapkan model pembelajaran talking stick ini dapat membantu siswa untuk lebih siap dalam belajar serta peserta didik harus dapat memahami pembelajaran yang telah diajarkan oleh guru sehingga ketika mendapatkan giliran untuk menjawab pertanyaan dari guru maka peserta didik itu telah siap dengan jawabannya.

Sehingga model pembelajaran talking stick memiliki pengaruh yang baik untuk peserta didik dimana dapat membantu peserta didik untuk dapat lebih aktif dan dapat meningkatkan keterampilan mengkomunikasikan pembelajaran sejarah dikelas. Dengan menerapkan model pembelajaran talking stick memberikan pengaruh yang baik untuk peserta didik, peserta didik dapat lebih nyaman dan santai dengan belajar sambil bermain tongkat (stick) sehingga pembelajaran sejarah dapat mudah dipahami peserta didik dengan cara memberikan pertanyaan yang saling bergantian kepada peserta didik. 


\section{DAFTAR PUSTAKA}

Agung, A.A.G, Widiana, IW \& Tresnayanti, P.I. 2017. Talking Stick Sebagai Inovasi Dalam Aktivitas Mengkomunikasikan Untuk Meningkatkan Pemahaman Siswa. Jurnal: Ilmiah Sekolah Dasar, 1(3),147-154.

Huda, M. (2013). Model-Model Pembelajaran dan Pembelajaran: Isu-Isu Metodis dan Paradigmatis. Yogyakarta: Pustaka Belajar.

Imas \& Berlin. (2016). Ragam Pengembangan Model Pembelajaran Untuk Meningkatkan Profesionalitas Guru. Jakarta: Kata Pena.

Lestari, N.K, Kristiantari, Mg.R. \& Ganing, N.N. 2017. Pengaruh Model Pembelajaran Talking Stick Berbantuan Lagu Daerah Terhadap Hasil Belajar. Journal of Education Research and Evalution, 1(4), 290-297.

Pour, A.N, Herayanti, L \& Sukroyanti, B.A. 2018. Pengaruh Model Pembelajaran Talking Stick Terhadap Keatifan Belajar Siswa. Jurnal: Penelitian dan Pengkajian Ilmu Pendidikan: e-Saintika, 2(1), 36-40.

Rianto, M. dkk. (2006). Pendekatan, Strategi dan Metode Pembelajaran. Departemen Pendidikan Nasional Direktorat Jenderal Peningkatan Mutu Pendidikan Dan Tenaga Kependidikan. Pusat Pengembangan Penataran Guru IPS dan PMP Malang.

Safitri, L. (2016). Penerapan Model Pembelajaran Talking Stick Untuk Meningkatkan Motivasi Belajar Siswa. Jurnal: Pendidikan dan Kependidikan.

Suprijono, A. (2009). Cooperative Learning: Teori \& Aplikasi Paikem. Surabaya: Pustaka Belajar.

Susanto, H. (2014). Seputar Pembelajaran Sejarah ; Isu, Gagasan dan Strategi Pembelajaran. Aswaja Pressindo: Yogyakarta.

Tiara, D. Pramudiyanti \& Marpaung, R.R.T. 2014. Pengaruh Model Pembelajaran Talking Stick Terhadap Afektif Receiving Dan Responding Siswa.

Undang-Undang Republik Indonesia Nomor 20 Tahun 2003 Tentang Sistem Pendidikan Nasional. 